\title{
Civilisations
}

Revue internationale d'anthropologie et de sciences

humaines

$54 \mid 2006$

Expériences de recherche en République

démocratique du Congo

\section{Remote Control Research in Central Africa}

\section{Theodore Trefon and Serge Cogels}

\section{(2) OpenEdition}

\section{Journals}

\section{Electronic version}

URL: http://journals.openedition.org/civilisations/405

DOI: 10.4000/civilisations.405

ISSN: 2032-0442

\section{Publisher}

Institut de sociologie de l'Université Libre de Bruxelles

\section{Printed version}

Date of publication: 1 April 2006

Number of pages: $145-154$

ISBN: 2-87263-006-6

ISSN: 0009-8140

\section{Electronic reference}

Theodore Trefon and Serge Cogels, « Remote Control Research in Central Africa », Civilisations [Online] 54 | 2006, Online since 01 April 2009, connection on 21 April 2019. URL : http://

journals.openedition.org/civilisations/405; DOI : 10.4000/civilisations.405

(C) Tous droits réservés 


\title{
Remote Control Research in Central Africa
}

\author{
Theodore TREFON and Serge COGELS
}

\begin{abstract}
Summary: This article explains how a project being implemented in peri-urban central Africa is coordinated from an office in Brussels. After an overview that addresses the conceptual challenges of defining 'peri-urban' and the question of why these social spaces are important from a development perspective, the article outlines 'remote control research'step-by-step: (i) conceptualisation, (ii) identification and recruitment of local experts, (iii) selection of research sites, (iv) the process of formulating a locally appropriate and detailed research protocol, (v) implementation and (vi) analysis of findings and presentation of results. The conclusion argues that research in central Africa will increasingly be influenced by donor priorities and will consequently need to respect the guidelines dictated by project cycle management strategies currently in vogue. The steps in the project cycle reflect the nature of the relationships between donors, researchers in the field and the intermediary project managers that link the two extremes. Accommodating the worldviews, expectations and constraints of these actors is something that, although not always easy, is possible when the right blend of conditions is respected.
\end{abstract}

Key words: peri-urban areas, research ethics, natural resource management, project cycle management, governance.

Résumé : Cet article explique comment un projet financé par l'Union européenne et coordonné depuis un bureau à Bruxelles est mis en œuvre dans des périphéries urbaines en Afrique centrale. Après avoir souligné les difficultés conceptuelles pour définir le concept de "périurbain " et l'importance de ces espaces pour le développement, les auteurs analysent étape par étape le processus d'une recherche contrôlée à distance : (i) la conceptualisation, (ii) l'identification et le recrutement des experts locaux, (iii) la sélection des sites de recherche, (iv) la formulation d'un protocole de recherche approprié au contexte et détaillé, (v) la réalisation de l'enquête et (vi) l'analyse des données ainsi que la présentation des résultats. Il apparaît en conclusion que la recherche en Afrique centrale sera de plus en plus dictée par l'agenda des bailleurs et devra de plus en plus se soumettre aux consignes de management de projets dans l'air du temps. Les étapes du cycle de projet reflètent la nature complexe des relations entre les bailleurs, les chercheurs de terrain et les gestionnaires de projet qui médiatisent ces deux premières catégories. Concilier les modes de pensée, les attentes et les contraintes de tous ces intervenants $n$ 'est pas facile, mais néanmoins possible sous certaines conditions.

Mots-clés : espace périurbain, déontologie de la recherche, gestion des ressources naturelles, cycle de gestion de projet, gouvernance. 


\section{Introduction}

$\mathrm{H}$ ow can a natural resource management project in central Africa be coordinated from an office in Brussels? What is the pertinence of an initiative that may be perceived as a bizarre twist of North-South cooperation - or worse, a notoriously outdated example of top-down intervention? What concrete steps are followed to keep up momentum and produce results? This article will address these issues by drawing on the experience of a four-year research-action project funded by the development branch of the European Commission ${ }^{1}$. At this stage of the project cycle, it is too early to present final results. It is however possible to present the research context, the steps of the project cycle, as well as the specific methodology used in the research sites.

Social science research throughout much of Africa since the 1980s has been marked by a clear shift away from a previously fashionable area studies approach (advocated by academics) towards problem-oriented actions implemented by a new corps of specialists, consultants and experts. This shift emanates largely from the development challenges faced by the continent with the result that research for research's sake is a luxury that fewer funding agencies are willing to support. The marginalization of Africa in the global political economy, real and perceived security concerns and the existence of other attractive research sites, for example in Latin America or Asia, are other factors that can account for this shift. For the sake of political correctness, funding frequently falls into the 'politically neutral' categories of environment, health, education, gender or children. Social science research in other words is increasingly influenced by donor priorities. Despite the disadvantages of donor-driven aid, there are also some positive implications. These include improved partnerships between policy-makers and researchers, new possibilities for academics to carry out action-research through socially pertinent actions and a greater sense of professionalism within the Ivory Tower.

The peri-urban research described in this article is clearly representative of this trend. The European Commission has manifested a commitment to working with social scientists in environmental management issues in the Congo Basin. Nonetheless, there is a consensus amongst grantees that negotiating a contract with the Commission is a complicated and bureaucratic obstacle course that requires patience ${ }^{2}$, perseverance, proven field experience, conceptual originality and a great deal of luck. This situation is exacerbated by the specific administrative requirements of the grantee, such as a consultancy office, research agency, NGO, or in our case, the University of Brussels.

\section{Conceptualising the peri-urban}

How do people living in the halos of central Africa's expanding cities cope with the challenges of natural resources management? What stakeholders groups are involved? How do local populations perceive and experience the new dynamics of environmental

1. This article deals with one of four research themes of GEPAC (Gestion participative en Afrique centrale). Information about GEPAC is available at $h t t p: / / w w w . u l b . a c . b e /$ socio/anthropo/Gepac/index.html

2. We were notified officially by the Commission that the project was accepted in January of 2002 and the contract was being prepared. We had practically no news until July of 2002 (in the middle of summer holidays) when the person managing the contract sent a lengthy series of questions by email on a Monday with the request : "please respond before Thursday if possible"! 
governance? Why are peri-urban areas socially, ecologically, politically and economically important from a development perspective? These are the questions studied in our work in peri-urban Kinshasa and Lubumbashi in the Democratic Republic of Congo and Brazzaville in the Republic of Congo. People living in these cities have gone through years of severe economic crisis and political turmoil, which continues to reconfigure the relations they have with their hinterlands ${ }^{3}$. New settlers, migrant traders and established residents converge in peri-urban areas to carry out economic activities such as farming, fuelwood harvesting and non-timber forest product extraction. Many of these activities are subsistence but commercial activities are also significant. These new settlements and economic patterns clearly put pressure on land tenure practices. These spaces are gradually developing the appearance of urbanised districts but infrastructure is not sufficient: haphazard urbanization processes are taking place without urban planning.

Peri-urban areas in central Africa are characterized by proximity to a densely populated urban settlement, rapid population growth, severe environmental degradation, hybrid governance structures that juxtapose State agencies and traditional authorities, extractive and productive economic activities for subsistence and trade (heavily dependant on natural resources and agriculture) and a 'hinge' dimension linking peri-urban areas to both cities and rural hinterlands. Local level factors in managing natural resources are of particular importance because institutionalized legal frameworks rarely correspond to the lived reality of ordinary people. Understanding the negotiation process between sets of actors is thus crucial. Environmental governance in this context depends on the juxtaposition of institutional factors and the political economy of communities.

State administrations have never fully come to terms with the importance of traditional authorities in these areas, and conversely, traditional authorities have never fully accommodated themselves with State actors. Despite the existence of varying intensities of tension and conflict caused by this hybrid juxtaposition, few local stakeholders or outside observers see the future as a zero-sum situation. The way forward can only be based on a mutual acceptance of this hybrid governance context by stakeholders at all levels. In a situation characterized by ambiguity, opportunism, greed and strikingly stratified power relations, finding the means of reaching such a consensus will necessarily entail allowing all stakeholders to gain some form of material or social advantage.

\section{Research context and methodology}

\section{Step 1: Conceptualisation}

Conceptualisation of the project started by identifying and ranking the social and environmental priorities of local stakeholders. This step in the project cycle benefited from previous work carried out by the two coordinators in the context of other action-research projects. Trefon, the architect of the project, has capitalized on experience from another EU funded project, Avenir des Peuples des Forêts Tropicales (APFT) that had a strong focus on forest-city relations (Trefon 1998, 1999, 2000a, 2000b) as well as on a project on land use changes around two mid-sized Gabonese cities funded by the United States

3. Brazzaville was the theatre of a series of protracted and extremely violent civil wars between 1993 and 2000. Rwandan and Rwandan-backed rebels entered Kinshasa in the summer of 1998 provoking what has now become known as la bataille de Kinshasa. 
Agency for International Development (Wolff et al. 1999, Mwanza et al. 2003). Cogels' expertise in conceptualising and supervising locally appropriate research techniques was achieved in Cameroon and Equatorial Guinea during ethnographic doctoral research, also in the framework of APFT (Cogels and Pasquet 1999, Cogels 2002) and by carrying out socio-economic surveys along the Chad-Cameroon petroleum pipeline (Cogels and Koppert 2004, 2005).

At the theoretical level, this joint expertise - achieved thanks to many years spent in the field with local researchers - helped us understand the social dynamics of peri-urban areas from a comparative perspective. It also gave us credibility and legitimacy in the eyes of local experts and authorities. Credibility and legitimacy are necessary ingredients in making remote control coordination workable. This is particularly true in DCR because Congolese are justifiably wary of the army of experts that have passed through the country for development work since the mid 1990s. Those of us who worked in the Zaire of Mobutu tend to enjoy a more favourable position than the new and generally younger arrivals.

This experience also enabled us to translate these social dynamics into a policy language that sparked the interest of the donor. The originality of the proposed work from the donor's point of view was welcome because the Commission funds projects in peri-urban areas (notably around Kinshasa) focusing on food security, infrastructure rehabilitation and development, environmental management and health. These projects, nonetheless, suffer from an insufficient understanding of local stakeholders' social organisation and expectations, hence the interest in supporting our work.

In addition to the need to clearly link theoretical dimensions with concrete development implications, it was also necessary to design a logical framework (a four column table comprised of a narrative summary of the project, expected results, performance indicators and assumptions/risk indicators), draw up a budget (a 'reasonable' estimation of needs and costs) and elaborate a calendar presenting activities month by month. These and other requirements were specified in the donor's call for proposals and had to be painstakingly respected. Adherence to these requirements eventually resulted in securing funding.

\section{Step 2: Local expertise}

Trefon's experience in Kinshasa helped him identify and train reliable and competent local experts. Working with the right people is another fundamental ingredient in making remote control coordination workable. They were selected on the basis of their academic qualifications, previous research experience, willingness to work in a team, capacity to meet deadlines and respect the strict demands of report writing. Their knowledge of environmental issues in the research area and their relationships with local authorities and other resource people, as well as their local language skills, were additional recruitment criteria. One mid-level expert is employed part-time per research site. We also hired a senior level Congolese coordinator ${ }^{4}$ based in Kinshasa on a part-time basis. His contributions include monitoring fieldwork, clarifying questions that our researchers may have, commenting on research activity reports, providing local logistical support and facilitating exchanges between the Brussels-based coordinators and the local team

4. Professor Shango Mutambwe, Assistant Director of the EU/UNESCO funded international forestry institute (ERAIFT) at the University of Kinshasa. 
members. His finesse in making sure that these collaborators are not intimidated by what they could perceive as a hierarchical relationship between the African researcher and the European who controls the purse strings is particularly helpful.

Identifying experts that meet these qualifications was not easy. There is clearly an imbalance between the vast majority of Congolese researchers and their counterparts in the North when dealing with complicated concepts such as governance or participatory approaches. There is also an imbalance with respect to research methods. Congolese researchers with strong publication records, while working and studying abroad, invariably see their production diminish once they return home. This situation can be accounted for by poor working conditions, lack of motivation, intellectual isolation and the crisis that the Congolese higher education system has gone through over the past 30 years.

Experts who do meet these requirements, moreover, are generally solicited by a multiplicity of NGOs and development projects. They are consequently unable to devote their full attention to a single contract. The long time lag between the conceptualisation of the project and the effective starting time (nearly three years!) also had a negative impact on the constitution of our team. One of the experts with whom we planned to work found another job before we were able to put him on the payroll. Although now obvious for younger researchers, recent access to the Internet, cell phones and Western Union style transfer agencies in central Africa is an absolutely fundamental condition in making remote control coordination workable. Prior to approximately the late 1990s, this type of coordination was much slower and far less efficient - in large part because mail between Brussels and Kinshasa, for example, generally had to be hand delivered.

\section{Step 3: Selection of research sites}

Two general considerations influenced our decision to work in these two Congo Basin countries. One, the tremendous challenges people are confronted with concerning access to natural resources and two, the original forms of social organisation they have set up to replace deficient state services. At the practical research level, as carrying out detailed social science investigation in the entire periphery around three cities would have been overwhelming, we selected two sites in the Kinshasa semi-rural commune of Maluku, located 80 kilometres from the city centre (Kimpoko and Maluku-cité), one site in the Lubumbashi Commune annexe (Kawama) eighteen kilometres from the city centre and the village of Loukanga I, eighteen kilometres outside of Brazzaville.

These sites were selected primarily for their economic and social 'hinge' characteristics. This refers to the ways that 'traditional' rural practices are linked with the adjacent city. Another factor for selection was the relatively easy access of public transportation (in the form of taxibus) between the research site and the city where our collaborators live and work. The fact that our collaborators can travel easily to their field sites is crucial to the long-term immersion strategy we have developed: it helps them create solid relationships with local populations. The resulting situation of trust means that access to sensitive information is facilitated in what is undeniably a difficult research climate. When Matthieu Kayembe started sleeping in a rudimentary guesthouse in Kawama, for example, people adopted him as a 'local boy', thus re-defining his image as an intellectual university researcher. Our collaborators identify themselves as university researchers instead of experts working on an internally funded project. People would otherwise expect money or other gifts from them. This strategy had a reverse effect however on one occasion for Noël Kabuyaya when students protested at the University of Kinshasa. He was in Maluku 
at the time and police agents detained him for a night as a form of revenge against the students who harassed police agents on campus. Noël was released the following day without his shoes, trousers and cell phone.

\section{Step 4: Research protocol}

Research questions were formulated over a period of approximately one year (year one of the four year cycle). The first steps here included a classic literature review, capitalization on the experiences mentioned above and a workshop in Kinshasa with a small interdisciplinary group of experts. A long exercise of drafting and re-drafting the protocol followed. Ultimately we were able to strike a workable balance between the demands and specificities of social science and ecological research within the individual research sites, while at the same time, reflecting donor priorities that could be translated into concrete actions.

Recourse to design and strict adherence to this protocol was not our initial plan. At first, we articulated broad research questions and asked our collaborators to address them according to the specificities and priorities of their sites. This quickly emerged to be unrealistic. The researchers did not fully understand what we expected from them, the data was not comparable and it would have made the task of presenting synthetic results unmanageable. Moreover some of the concepts that we considered as being crucial were avoided by our collaborators because they either had difficulty in understanding them, for example the concept of "local political arena" (Olivier de Sardan 2005) or because they did not appear to be locally pertinent. Despite the question-by-question structure of the protocol, some snags pertaining to interpretation continue to emerge. Alfred Nkodia, the expert working in Loukanga I, for example, expressed marked frustration when we asked him to offer more details in one report after having asked him to be more synthetic in a previous report.

The protocol that has resulted from this richly iterative process is a long list of questions divided into six sets of activities. As it is a lengthy document, approximately 30 pages, we do not have the space here to reproduce it in its entirety ${ }^{5}$. The major headings of the protocol are nonetheless presented below (table 1). The degree of detail in this questionnaire was absolutely necessary to make sure that the local experts understand exactly what we expect from them and to make sure that they provide comparatively useful responses. Each question and sub-question was attributed a number to facilitate the quality control and the synthesis work of the two Brussels-based coordinators. For example, by looking at question 3.1.4, we can readily access information about which procedures civil society actors need to follow and what documents are required for them to gain access to land.

5. It is published elsewhere : Trefon, T. and S. Cogels (2005). 


\begin{tabular}{|c|}
\hline Table 1 Summary of Research Protocol \\
\hline Activity I: Characterization of peri-urban space \\
\hline $\begin{array}{l}\text { The first series of research questions seeks to characterize the peri-urban space being studied by using a } \\
\text { multivariate and comparative approach. The three broad sets of variable are (i) the geo-physical setting, } \\
\text { (ii) demographic and social factors and (iii) peri-urban residents' perceptions of themselves and their } \\
\text { environment. The goal is to identify contrasts and similarities that will help us conceptualize what is } \\
\text { meant by peri-urbanity to better understand how people live in and perceive these particularly challenging } \\
\text { social spaces. }\end{array}$ \\
\hline Activity II: Inventory of governance actors and their involvement in natural resource management \\
\hline $\begin{array}{l}\text { The objective here is to identify all the actors involved in natural resource exploitation or management, } \\
\text { categorize them according to 'strategic groups', and analyze the relationships between these different } \\
\text { sets of actors. This work draws on the theory of political arenas to understand how these sets of actors } \\
\text { interact. The processes of negotiation between actors are crucial here, as is their degree of accommodation } \\
\text { and conflict. The local, national and international political contexts are addressed in this section which } \\
\text { will ultimately help respond to the overriding questions of who has power over natural resources in the } \\
\text { research site and what is the impact of this power on the environment. This section will also take into } \\
\text { account the way people perceive the challenges of environmental management and the ways of improving } \\
\text { it and making it more participatory. }\end{array}$ \\
\hline Activity III: Access to natural resources and peri-urban space \\
\hline $\begin{array}{l}\text { To respond to the question 'how do people gain access to resources in peri-urban areas?' this section } \\
\text { focuses on the negotiation processes between stakeholders. It addresses the rights and practices that } \\
\text { enable people to access resources individually and collectively. }\end{array}$ \\
\hline Activity IV: Analysis of conflict and resolution mechanisms \\
\hline $\begin{array}{l}\text { The objective of this activity is to identify all forms of environmental conflict in the research site and the } \\
\text { strategies designed to resolve them. Questions in this section are raised in a way that provides information } \\
\text { on environmental issues. The first step is to interview a sample of actors from each strategic group and } \\
\text { get them to respond to the questions about their involvement in conflicts over natural resources. The } \\
\text { information collected from these questions is necessary to establish a typology of conflicts which is the } \\
\text { second step in this activity. The third step in this activity is to describe conflict management strategies in } \\
\text { these categories. }\end{array}$ \\
\hline Activity V: Inventory of economic activities in the research sites \\
\hline $\begin{array}{l}\text { The information required here is less conceptual then the previous ones and is more matter-of-fact. } \\
\text { The objectives are to have an overall picture of economic activities in the research site, understand the } \\
\text { environmental impacts of these activities and analyse local dynamics of credit and savings. This can } \\
\text { be done by inventorying economic activities, identifying all economic actors, studying the perceptions } \\
\text { stakeholders have about the impact of their activities on the environment and the sustainability of their } \\
\text { activities and finally describing the financial dimensions of these environmental economic activities. }\end{array}$ \\
\hline $\begin{array}{l}\text { Activity VI: Relations between the peri-urban site and its rural hinterland and relations between the peri- } \\
\text { urban site and the city }\end{array}$ \\
\hline $\begin{array}{l}\text { The objective of this activity is to describe the links between the peri-urban area and adjacent social } \\
\text { spaces. This pertains to social and economic links, trade networks and perceptions that peri-urban } \\
\text { populations have of themselves, their social space and their counterparts in the city or in the hinterland. } \\
\text { The sub-sections are: links between people in the peri-urban area and their family in the rural hinterland; } \\
\text { commercial relations between the peri-urban area and the rural hinterland; links between peri-urban } \\
\text { populations and city dwellers, commercial relations between the peri-urban area and city dwellers and } \\
\text { perceptions that peri-urban populations have of the city and city dwellers. }\end{array}$ \\
\hline
\end{tabular}




\section{Step 5: Implementation}

Once the research protocol was finalised, the research sites selected and the researchers identified, work in the field started. Fieldwork corresponds to years two and three of the project. Trefon travels to the field approximately every three to four months to consult with members of the research team and other resource people. These missions are crucial not only to monitor the quality of the field research but to also maintain good working relationships with the local experts. Research and report writing is a part-time occupation for the experts, that requires approximately two months per activity. Fees are paid to the experts upon reception of their activity reports. These reports are reworked for content (insuring that every point in the protocol is addressed), depth of analysis and writing style on an average of three or four times before being mutually accepted as final. In the beginning of the report writing process, our researchers condemned us as being perfectionists and 'sticklers' but eventually came to appreciate that our demands significantly improved their research, writing and analytical skills. Remote control coordination in this sense contributes significantly to local capacity building.

\section{Step 6: Analysis of findings and presentation of results}

Analysis of findings and synthesis report writing (second semester of year three and beginning of year four) will be the work of the Brussels coordinators. We will start by comparing the data from the three sites, question by question. Contrasts and similarities will be synthesised and presented in a two-column table: one column with the questions, the other with the synthetic findings. One such table per activity, meaning six tables, will thus be elaborated. A segment is presented below (table 2). In a second phase, we will draw on these tables to elaborate a narrative text written in a language accessible to donors and other decision makers. This version of the analysis will highlight the expectations and needs of peri-urban stakeholders, reflecting the approach carried out during the research phase.

The collaboration with our local research team, however, will not end once they will have submitted their six reports. During the synthesis phase they will be solicited to clarify whatever ambiguities are likely to remain. Next, our draft reports will be submitted to them for their control and approval. This restitution is a crucial step in remote control coordination and is a logical step in the best practices of professional ethics. It culminates the North-South research collaboration by emphasising that it is indeed the local researchers who are the real experts in their sites. It should also reinforce our relations by proving that we are not trying to unilaterally exploit their work. At the outset it was made clear to our collaborators they can capitalise on our collective experience at their own levels in whatever ways they choose. Concrete examples include leveraging for funding, pursuing university degrees, publishing articles or carrying out further consultancies. 


\begin{tabular}{|l|l|}
\hline \multicolumn{2}{|c|}{ Table 2 } \\
\hline Questions & Synthesis from the three sites \\
\hline are present in the site? & $\begin{array}{l}\text { State actors are present in all of the sites, particularly Maluku } \\
\text { where 26 services are represented. The contrast between the strong } \\
\text { presence of security services and the absence of social services is } \\
\text { striking. }\end{array}$ \\
\hline How efficient are they? & $\begin{array}{l}\text { There are three levels of efficiency: } \\
\text { - In the three sites, basic services (e.g. Population) or technical } \\
\text { support (Farming and Animal Husbandry) exist more in theory } \\
\text { than in practice. } \\
\text { - Given the opportunities for formal and informal taxation, } \\
\text { services linked to natural resource exploitation are active (Land } \\
\text { Registration, Water and Forestry). } \\
\text { - Police, Customs and Security agents are omnipresent and } \\
\text { efficient in controlling the movement of people and goods. }\end{array}$ \\
\hline $\begin{array}{l}\text { How do local stakeholders } \\
\text { perceive them? }\end{array}$ & $\begin{array}{l}\text { The predatory nature of these State agents is confirmed in our } \\
\text { findings: } \\
- \text { "When we can avoid a State agent, we do so. If he can't be } \\
\text { avoided, we negotiate and pay the smallest amount possible": } \\
\text { vegetable grower, Maluku. } \\
- \text { "Agents prefer being posted to positions where they can get a } \\
\text { few crumbs from us": trader, Loukanga I. } \\
\text { - "We are the hens that lay golden eggs for the State": charcoal } \\
\text { transporter by bicyle, Kawama. }\end{array}$ \\
\hline
\end{tabular}

\section{Conclusion}

Research in central Africa will increasingly be influenced by donor priorities and will consequently need to respect the guidelines dictated by project cycle management strategies currently in vogue. The various steps in the project cycle described above reflect the present nature of the relationships between donors, researchers in the field and intermediary project managers that link the two extremes. This approach, despite some ethical and operational handicaps, does nonetheless have the potential of supporting the efforts of development planners, project officers, natural resource managers and NGOs working in what have become very challenging social spaces. Researchers working in other peri-urban areas can adapt this approach to harmonize local specificities with broader natural resource or development objectives. The authors of this paper - the remote control coordinators of this project - serve as intermediaries between donors and local researchers. We navigate between the bureaucratic intricacies of a major development agency and the complexities of local-level field work in central Africa. Accommodating the worldviews, expectations and constraints of both sets of partners is something that, although not always easy, is possible when the right blend of conditions is respected. 


\section{References}

Cogels, Serge and Patrick Pasquet, 1999. "Vivre à Mvi'ilimengalé: activités quotidiennes et gestion du temps chez les Ntumu du Sud-Cameroun”, in Serge Bahuchet, Daniel Bley, Hélène Pagezy and Nicole VernazzaLicht (eds), L'homme et la Forêt tropicale, pp. 175-189. Châteauneuf de Grasse : Editions de Bergier.

Cogels, Serge, 2002. Les Ntumu du sud-Cameroun forestier: une société de non-spécialistes. Système de production, stratégies d'usage des ressources et enjeux du changement, thèse de doctorat, Université libre de Bruxelles.

Cogels, Serge and Georgius Koppert, 2004, 2005. Socioeconomic Baseline and Monitoring Surveys in the Chad Oil Field Development Area and Pipeline Corridor. Paris: GEPFE.

Mwanza, Hugo, Eléonore Wolff and Theodore Trefon, 2003. "Mutations socio-économiques et évolution des pratiques agricoles dans les espaces autour des villes moyennes en Afrique subsaharienne; le cas gabonais", in Tomke Lask (ed.), Constructions sociales de l'espace. Les territoires de l'anthropologie de la communication, pp. 76-192. Liège: Les Editions de l'Université de Liège.

Olivier de Sardan, Jean-Pierre, 2005. Anthropology and Development: Understanding Contemporary Social Change. London: ZED Books.

TREFON, Theodore

1998. "Urban Threats to Biodiversity in the Congo Basin", in Cas Besselink and Peter Sips (eds), The Congo Basin: Human and Natural Resources, pp. 89-99. Amsterdam: IUCN.

1999. "Libreville et son appétence opiniâtre de forêt”, Afrique Contemporaine, 190, pp. 39-54.

2000a. "Population et Pauvreté à Kinshasa", Afrique Contemporaine, 194, pp. 82-89.

2000b. "Forest-City Relations" in Serge Bahuchet (ed.), Les peuples des forêts tropicales aujourd'hui, vol. II. Une approche thématique, pp. 305-330. Bruxelles : APFT-ULB.

Trefon, Theodore and Serge Cogels, 2005. "A Stakeholder Approach to Natural Resource Management in Peri-urban Central Africa”, in Morgan De Dapper (ed.) Tropical Forests in a Changing Global Context, pp. 97-221. Brussels: Royal Academy of Overseas Sciences,

Wolff, Eléonore, Theodore Trefon, Marie Sintzoff and Hugo Mwanza, 1999. "Des villes qui grignotent la forêt au Gabon", Revue belge de géographie, 4, pp. 277-293. 